Article

\title{
Using Multiple Discriminant Analysis for the Assignment of Initial Water Entitlements at River Basin-Level under the Strictest Water Resources Management System Constraints in China
}

\author{
Min Ge ${ }^{1}$, Fengping $\mathrm{Wu}^{2, *}$ and Xiaoping Chen ${ }^{3}$ \\ 1 School of Business Administration, Hohai University, No.200 Jinling North Road, Changzhou 213022, China; \\ gemin@hhu.edu.cn \\ 2 School of Business, Hohai University, No.8 Focheng West Road, Nanjing 211100, China \\ 3 School of Computer Engineering, Jiangsu University of Technology, No.1801 Zhongwu Road, \\ Changzhou 213001, China; chenxp@jsut.edu.cn \\ * Correspondence: wfp@hhu.edu.cn; Tel.: +86-25-5809-312
}

Received: 28 September 2018; Accepted: 21 November 2018; Published: 26 November 2018

check for updates

\begin{abstract}
From the perspective of system science, in China, an assignment system of initial water entitlements at the river basin-level can be divided into two subsystems, namely the assignment subsystem of initial water entitlements at the province-level and government reserved water at the river basin-level. Under the new backdrop of implementing the strictest water resources management system (SWRMS), we propose a novel methodological framework for addressing the in-coordination of pre-allocation plans between two subsystems for Lake Tai Basin, China. First, considering total water use, pollutant discharge and water use efficiency, we establish several criteria for the discriminant analysis of pre-allocation plans. Whilst based on these criteria, we built a comprehensive discriminant criterion to further verify coupling and coordination of pre-allocation plans between two subsystems. Second, according to uncoordinated or less coordinated situations, we propose adjusted strategies to decide the direction (increase or decrease) of the adjustment for pre-allocation plans of two subsystems. Third, taking coupling and coordination as optimal objectives, and considering total water use, total pollutant discharge and water use efficiency as constraints, we built an adjusted decision-making model for the assignment of initial water entitlements of the basin. Finally, the results of this novel discriminant analysis methodology that were applied to the Lake Tai Basin show that under the water frequency of 75\%, in the planning year 2030, Jiangsu Province is assigned the most initial water entitlements at the province-level, followed by Shanghai and Zhejiang Province. In this paper, results are generally in accordance with pilot plans released by China's Ministry of Water Resources. Apart from pilot plans, our findings also show the assignment plans for government reserved water at the river basin-level, which is coordinated and coupled with assignment plans for initial water entitlements at the province-level. The novel methodological framework of this paper can also be applied as a reference to other similar river basin.
\end{abstract}

Keywords: the strictest water resources management; initial water entitlements; government reserved water; subsystem; discriminant criterion; water resources sustainability

\section{Introduction}

Water is the basic source of life, the crucial key to production, an important foundation of ecology and is also the principal guarantee for sustainable development. Along with Earth entered the Anthropocene [1,2], and the interactions and conflictions between humankind and water are 
increasing [3-5]. In response to overuse by humans and anthropogenic climate change, freshwater availability is changing [6]. In addition, with the growing population, in-depth industrialization and urbanization, water crisis is still recognized as the core risk of global society $[7,8]$ and China is not an exception. In fact, in China, enormous population, inadequate fresh water resources per capita and uneven temporal and spatial distribution of water resources is the national situation. In the meantime, water regime is coupled with severe water scarcity, severity of droughts, increasing pollution and degenerating aquatic ecosystems [9].

On 12 January, 2012, in order to accelerate the construction of a water-saving society, so as to promote the water use efficiency and safeguard sustainable socioeconomic development, China's State Council explicitly promulgated the practice of the Strictest Water Resources Management System (SWRMS), which established "Three Red Lines" as core elements [10]. "Three Red Lines" includes the first line of strictly controlling the excessive growth of total water use quantity, the second line involves strictly controlling total pollutants discharged into rivers and lakes, and the third line involves effectively improving water use efficiency [11].

The recognition of water risk and the implementation of SWRMS have led China to build a legislation framework of the water market, including the initial water entitlements, the water licensing and the water entitlements trade-off strategy, thereby facilitating the reallocation of scarce water resources across competing demands in China. In fact, worldwide, the theoretical research and practical experiences of some countries, namely Australia, Chile, the United States and Spain, also have shown that water market systems make water usage more efficient [12-22]. However, if property entitlements are well-defined without transaction costs, the initial assignment of it matters for efficiency [23]. When the initial water rights are clearly defined and quantified, each water user can understand how much water they are entitled to use [24]. Therefore, in China, the assignment of initial water entitlements is a very essential prerequisite and foundation for the development of China's water market.

Commonly, entitlements are defined as resources. One can establish ownership or command access to resources through entitlements [25]. With regard to water entitlements, however, from various aspects, different literature provides different understandings. In this paper, the water entitlements only refer to the surface water entitlements, which means the rights to allocate, take or use the surface water resources rather than legal ownership rights. In addition, from the perspective of system science, the assignment system of the initial water entitlements at the river basin-level can be divided into two subsystems, namely the subsystem of initial water entitlements at the province-level and the subsystem of government reserved water at the river basin-level. However, the initial water entitlement at the province-level is a quota that is supplied to meet reasonable water consumption of provinces [9], and the government reserved water at the river basin-level is water that is reserved and managed by the central government or a certain designated organization to prevent unforeseeable future events and emergencies [26]. At present, how to develop a fair, reasonable and efficient assignment for the initial water rights between these two subsystems of a typical river basin has already turned into a new challenge for implementing the SWRMS in China.

Lake Tai Basin is a large shallow lake and is also the third largest freshwater lake in east China. It is one of the most densely populated and economically developed regions in China. In recent years, due to the rapid development of population growth, urban expansion and the local economy [27], the gap between water supply (average annual amount is 196 hundred million $\mathrm{m}^{3}$ ) and water demand (average annual amount is 365 hundred million $\mathrm{m}^{3}$ ) is great [28]. Furthermore, the wastewater from cities and the surrounding agricultural and industrial sectors results in the deterioration of water quality $[29,30]$. In order to facilitate sustainable development, Lake Tai Basin was chosen as a pilot basin for the assignment of initial water entitlements in China.

In recent years, significant efforts have been made to explore the assignment of initial water entitlements of Lake Tai Basin from various respects. The three most important aspects are as follows:

- Firstly, theoretical studies on the assignment of initial water entitlements at the province-level, which have gradually developed from using the multi-objective method [31-38] and the method 
by coupling with multi-model [28,39-41], and have now progressed to establish the dual control models of water quantity and quality [42-46]. Though these studies made some progress based on optimization modeling, little attention was paid to the government reserved water which should be considered simultaneously during the assignment of initial water entitlements.

- Secondly, along with considerations of the ecological environmental protection and the social sustainable development, subsequent studies start to concern the assignment of government reserved water at the river basin-level. Recently, studies about this part include four categories, namely the necessity of government reserved water [47], the assignment principles of government reserved water [48], the assignment method (a combination of case-based reasoning and quota method [49,50], the reasoning method [51]), the basic constitution and order of precedence for the assignment of government reserved water [52].

- And finally, theoretical studies on coupled and coordinated assignment in the water resource system. Coupling is a term of physics which refers to the interaction between subsystems and their sub-elements. Some studies have developed models to analyze the coordinated and coupled development between the water resource system and another system, namely urban economy and water use efficiency [53], water resources scarcity and social adaptation capacity [54], ecology-economy-society system [55], water resource and urban development [56]. However, no attempt has been made to couple the assignment subsystems of initial water entitlements at the province-level and government reserved water at the river basin-level. Furthermore, under the new background of implementing SWRMS in China, the existing studies barely abide to the context of the new guidance of "Three Red Lines". Therefore, within the framework of the strictest water resources management, it is urgent to ensure coupling and coordination between two subsystems to acquire the rational assignment plans of initial water entitlements of the basin.

This paper tries to address the problem about the assignment of initial water entitlements for Lake Tai Basin, China. In the paper, we make a methodological contribution. We carry out a new coupled assignment model of the initial water entitlements applied to Lake Tai Basin, China. This methodology establishes a novel framework of addressing in-coordination of pre-allocation plans between the above subsystems to meet the "Three Red Lines" requirements. It offers a powerful tool for adjusting pre-allocation plans optimally in order to finally acquire a proper, fair, efficient, harmonious and mutually beneficial assignment plan. It can also be easily applied to case studies of similar river basin.

\section{Materials}

\subsection{Study Area}

This study was conducted in Lake Tai Basin, China. Lake Tai Basin is located in southern Yangtze River Delta. It is surrounded by either river or coast on three sides and occupies a strategic location. The whole Lake Tai ranges almost from $30^{\circ} 55^{\prime} 40^{\prime \prime}-31^{\circ} 32^{\prime} 58^{\prime \prime} \mathrm{N}$ to $119^{\circ} 52^{\prime} 32^{\prime \prime}-120^{\circ} 36^{\prime} 10^{\prime \prime} \mathrm{E}$. It is a representative shallow basin and is also the third largest freshwater lake in China. The maximum length and width are, respectively, almost $68.5 \mathrm{~km}$ and $56 \mathrm{~km}$. The average depth of Lake Tai is about $1.9 \mathrm{~m}$ [29]. Lake Tai Basin features a subtropical monsoon climate, the average annual air temperature is $16.1^{\circ} \mathrm{C}$ to $18.3{ }^{\circ} \mathrm{C}$, the average annual precipitation is almost $1101 \mathrm{~mm}$ to $1150 \mathrm{~mm}$ and $60 \%$ of the total precipitation occurs during May to September [30].

Lake Tai Basin is one of the most economically developed and most densely populated areas in China. Lake Tai Basin's administrative regions are mainly composed of Jiangsu Province, Shanghai City and Zhejiang Province which can be presented in Figure 1. Due to the rapid development of urban expansion population growth and the local economy, Lake Tai Basin suffers from harmful water pollution resulting in the deterioration of the water quality. 


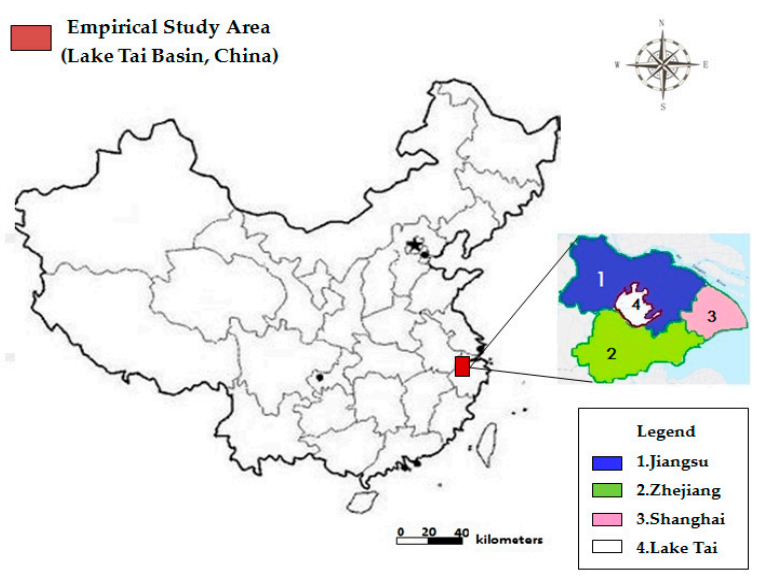

Figure 1. The location of Lake Tai Basin.

\subsection{Data}

The related water resources data in this paper were collected from materials of "Water resources plan of Lake Tai Basin (2012-2030)". The relevant socio-economic data were primarily gotten from official reports of LTAMWR (Lake Tai Basin Authority of Ministry of Water Resources). The other data were collected by Lake Tai Basin's partial survey data. There are some general scenarios of water frequency, such as water frequency of $25 \%, 50 \%$ and $75 \%$ [57-60]. In this paper, we use water frequency of $75 \%$ as an example. The meaning of the "water frequency of $75 \%$ " is that during the past 100 years, 75 years reached this water quantity. Other water frequency scenarios can be analyzed the same way. Aiming for the water frequency of $75 \%$ and the planning year 2030, according to the materials of "Water resources plan of Lake Tai Basin (2012-2030)", the total quantity of initial water entitlements and the total pollutant discharge of Lake Tai Basin are, respectively, 363.3 hundred million $\mathrm{m}^{3}$ and 54.46 hundred million $\mathrm{m}^{3}$. We use these abovementioned two indicators as the control quotas (the red line) for total water use and total pollutant discharge of our model, respectively. The related data of Lake Tai Basin under the water frequency 75\% and in the planning year 2030 is presented in Table 1. Furthermore, the assumptive pre-allocation plans of initial water entitlements for the two subsystems is shown in Table 2.

Table 1. Related data in Lake Tai Basin (under the water frequency of $75 \%$ and in the planning year 2030).

\begin{tabular}{ccccc}
\hline Index & $\begin{array}{c}\text { Population } \\
\text { (Hundred Million } \\
\text { People) }\end{array}$ & $\begin{array}{c}\text { Irrigated area } \\
\text { (Hundred Million Ha) }\end{array}$ & $\begin{array}{c}\text { GDP } \\
\text { (Hundred Million Yuan) }\end{array}$ & $\begin{array}{c}\text { Current Water } \\
\text { Consumption Amount } \\
\text { (Hundred Million } \mathbf{M}^{\mathbf{3}} \text { ) }\end{array}$ \\
\hline Jiangsu province & 1504.00 & 208.46 & $47,225.51$ & 193.5 \\
\hline Zhejiang Province & 655.45 & 254.43 & $27,129.68$ & 50.1 \\
\hline Shanghai & 1981.78 & 230.65 & $45,293.19$ & 99.7 \\
\hline
\end{tabular}

Table 2. The pre-allocation plans of the initial water entitlements of two subsystems in Lake Tai Basin (Unit: a hundred million $\mathrm{m}^{3}$ ).

\begin{tabular}{|c|c|c|c|c|c|}
\hline & \multicolumn{2}{|c|}{ Pre-Allocation Plans in Different Provinces } & $\begin{array}{c}\text { Jiansu } \\
\text { Province }\end{array}$ & $\begin{array}{l}\text { Zhejiang } \\
\text { Province }\end{array}$ & Shanghai \\
\hline Subsystem 1 & $\begin{array}{c}\text { Amount of initial water } \\
\text { entitlements at } \\
\text { province-level }\end{array}$ & & $W_{1}=176.99$ & $W_{2}=93.11$ & $W_{3}=85.3$ \\
\hline \multirow[t]{2}{*}{ Subsystem 2} & \multirow{2}{*}{$\begin{array}{l}\text { Amount of government } \\
\text { reserved water of the basin }\end{array}$} & $\begin{array}{l}\text { Public water use for } \\
\text { different provinces }\end{array}$ & $Z_{1}=2.50$ & $Z_{2}=1.03$ & $Z_{3}=1.21$ \\
\hline & & $\begin{array}{c}\text { Public water use for Lake } \\
\text { Tai Basin }\end{array}$ & & $Z_{g}=3.16$ & \\
\hline
\end{tabular}




\section{Methodology}

In China, the assignment for the initial water entitlements at the river basin-level is now confronting the new constraints of SWRMS with the key content of the "three red lines" control. Our new framework in this paper will follow these two phases including a "discriminant analysis of the pre-allocation plan" and "adjustment for the pre-allocation plan ", which are illustrated in Figure 2.

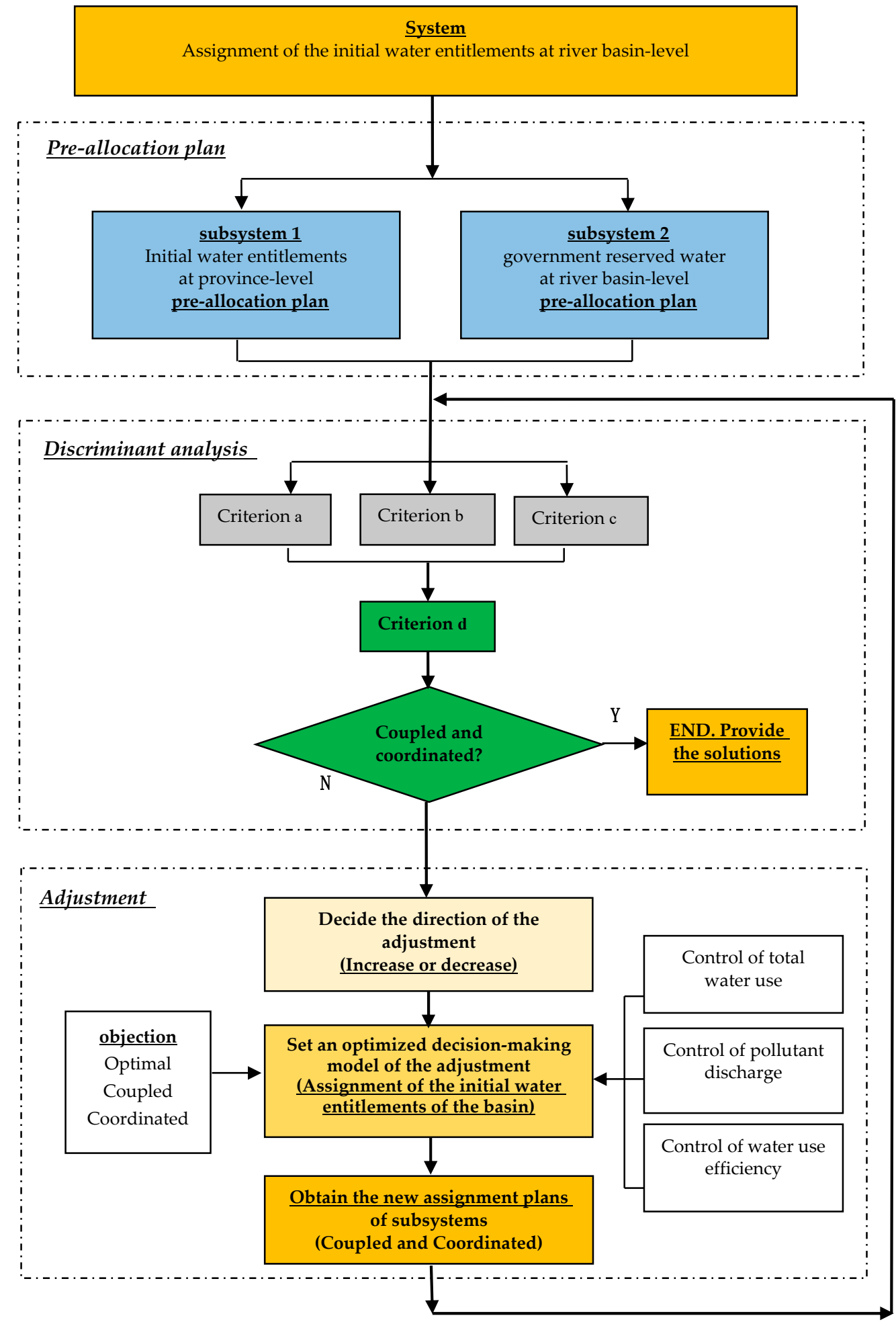

Figure 2. Outline of our methodology. 


\subsection{Description of the Outline}

\subsubsection{Phase I: Discriminant Analysis of the Pre-Allocation Plan}

In Figure 2, in order to verify the coupling and coordination of the pre-allocation plans between the two subsystems, four discriminant criteria were built and are described as follows:

- Criteria a: the total water use criteria. For the two pre-allocation plans of the subsystems, the total water use should be kept to the satisfying requirements of "the first red line control" at both the province-level and the river basin-level.

- Criteria b: the pollutant discharge criteria. For those two pre-allocation plans of the subsystems, the pollutant discharge should achieve demands of "the second red line control" at both the province-level and the river basin-level.

- Criteria c: the water use efficiency criteria. For the two pre-allocation plans of the subsystems, water use efficiency should meet the requirements of "the third red line control" at the province-level and the river basin-level.

- Criteria d: the coupling and coordination criteria. Based on criteria a, criteria b and criteria $c$, the coupling and coordination criterion should be applied to assess whether the two subsystems are well coordinated.

\subsubsection{Phase II: Adjustment for the Pre-Allocation Plan}

The adjustment of the pre-allocation plan will be conducted in two steps to solve the discordance for the subsystem of the initial water entitlements at the province-level and the subsystem of the government reserved water at the river basin-level.

- Step 1: Decide the direction of the adjustment of the pre-allocation plans for the two subsystems. We should identify the increase or the decrease direction of each subsystem according to the assessment based on criteria $a$, criteria $\mathrm{b}$ and criteria $\mathrm{c}$.

- Step 2: Establish an optimal decision-making model for the adjustment of the assignment of the initial water entitlements of the basin. First, set the optimized object functions for the purpose of promoting the coupling and coordination between the two subsystems. Second, we should design constraint conditions in terms of the control of total water use, pollutant discharge and water use efficiency. Then, we can obtain an optimal assignment model for the adjustment of the initial water entitlements at the river basin-level. And with the feedback of the adjusted pre-allocation plans, we should repeat Step 1 and Step 2 again until the ultimate assignment of the initial water entitlements satisfies the requirements of all of the discriminant criteria.

\subsection{Criteria Design}

Assume that $D=\left\{d_{1}, d_{2}, \cdots, d_{n}\right\}$ is the province set of a certain basin, $\left\{W_{1}, W_{2}, \cdots, W_{n}\right\}$ is the pre-allocation plan set for the subsystem of the initial water entitlements at the province-level, where $W_{j}$ is the water entitlements quantity of the province $d_{j} .\left\{Y_{1}, Y_{2}\right\}$ is the pre-allocation plan set for the subsystem of the government reserved water at the river basin-level, where $Y_{1}$ is the quantity of the emergency reserved water and $Y_{2}$ is the quantity of the development reserved water. Considering the subsystem of the government reserved water at the river basin-level, based on the case analysis combined with the relevant development planning, we distribute the government reserved water into two parts. One part is the public water use for the basin which can be presented as $Z_{g}$, the other part is the public water use for different provinces which can be indicated as $Z_{j}$, where $j=1,2, \ldots, n$. Then, we can obtain Equation (1).

$$
Y_{1}+Y_{2}=Z_{g}+\sum_{j=1}^{n} Z_{j}
$$


The purpose of the discriminant analysis for coupling and coordination between the subsystem of initial water entitlements at the province-level and subsystem of government reserved water at the river basin-level is to ensure the rationality of the total basin water use, reduce the basin pollutant discharge, enhance the basin-wide water use efficiency and support the sustainable development of the basin. In order to achieve the most satisfying assignment plan for the initial water entitlements of the whole basin, according to the ultimate goal of coordinated allocation and constraints of "three red lines", we designed the discriminant criteria from the following three dimensions: the total water use, the total pollutant discharge and the water use efficiency. Besides, further integrated coupling coordination criterion will also be set.

\subsubsection{Criteria a: Discriminant Criteria of the Total Water Use}

Criteria a: the discriminant criteria of the total water use includes two aspects: the scale and the structure. The scale criteria includes criterion $\mathrm{a}_{1}$ and criterion $\mathrm{a}_{2}$. The structure criteria includes criterion $\mathrm{a}_{3}$ and criterion $\mathrm{a}_{4}$.

- Criterion $\mathbf{a}_{1}$ : discriminant of the total water use in a basin is expressed by Equation (2).

$$
\sum_{j=1}^{n} W_{j}+\left(Z_{g}+\sum_{j=1}^{n} Z_{j}\right) \leq W_{L H}
$$

where $W_{L H}$ is the control quota (the red line) for the total water use of the basin.

- Criterion $\mathbf{a}_{2}$ : the discriminant of the total water use in different provinces is presented by Equation (3).

$$
W_{j}+Z_{j} \leq W_{j H}
$$

where $W_{j H}$ is the control quota (the red line) for the total water use of the province $d_{j}, j=1,2, \ldots n$.

- Criterion $a_{3}$ : the discriminant analysis of the rationality for the proportion of the water amount between the government reserved water and the available water of the basin. It can be illustrated by Equation (4).

$$
\alpha_{\min } \leq\left(Z_{g}+\sum_{j=1}^{n} Z_{j}\right) / W_{L H} \leq \alpha_{\max }
$$

where $\left[\alpha_{\min }, \alpha_{\max }\right]$ is the rational interval for the proportion of the water amount between the government reserved water and the available water of the basin.

- Criterion $\mathbf{a}_{4}$ : the discriminant analysis of the rationality for the quantity structure of water entitlements between different provinces. Set $H_{j 1}$ to the population of province $d_{j}$. Set $H_{j 2}$ to the irrigated area of province $d_{j}$. Set $H_{j 3}$ to the GDP of province $d_{j}$. Let $H_{j 4}$ denote the current water use of the province $d_{j}$. According to "province pair" $\left(d_{j}, d_{k}\right)$, its weighted comprehensive ratio of the social economic indicator is presented by Equation (5).

$$
\gamma_{\left(d_{j}, d_{k}\right)}=\sum_{q=1}^{4} \omega_{q}\left(H_{j q} / H_{k q}\right)
$$

where $q=1,2,3,4, \omega_{q}$ is the weight coefficient. This can be obtained by considering the actual provincial situation and the expert opinion approach together. The ratio of the water allocation between province $d_{j}$ and province $d_{k}$ should maintain a certain relationship to match each other. It can be expressed by Equation (6).

$$
\left(W_{j}+Z_{j}\right) /\left(W_{k}+Z_{k}\right) \in\left[\eta_{\min } \cdot \gamma_{\left(d_{j}, d_{k}\right)}, \eta_{\max } \cdot \gamma_{\left(d_{j}, d_{k}\right)}\right]
$$


where $j, k=1,2, \ldots n, j \neq k, q=1,2,3,4, \eta_{\min }$ and $\eta_{\max }$ are coefficients of the lower limit and upper limit which respectively reflect the matching relationship between the initial water entitlements at the province-level and comprehensive socio-economic indexes.

\subsubsection{Criteria b: Discriminant Criteria of the Total Pollutant Discharge}

Criteria b: the discriminant criteria of the total pollutant discharge also includes two aspects: the scale and the structure. The scale criteria includes criterion $b_{1}$ and criterion $b_{2}$. The structure criteria includes criterion $b_{3}$.

- Criterion $\mathbf{b}_{1}$ : the discriminant analysis for the total pollutant discharge of the basin can be presented by Equation (7).

$$
\sum_{j=1}^{n} Q_{j}\left(W_{j}+Z_{j}\right)+Q_{g} \cdot Z_{g} \leq Q_{L H}
$$

where $Q_{j}$ is the coefficient of the unit pollutant discharge for province $d_{j}, Q_{g}$ is the coefficient of the unit pollutant discharge for the public water use and $Q_{L H}$ is the control quota (the red line) for the total pollutant discharge of the basin.

- Criterion $\mathbf{b}_{2}$ : the discriminant analysis for the pollutant discharge in different provinces can be presented by Equation (8).

$$
Q_{j} \cdot\left(W_{j}+Z_{j}\right) \leq Q_{j H}
$$

where $Q_{j H}$ is the control quota (the red line) for the pollutant discharge of province $d_{j}, j=1,2 \ldots n$.

- Criterion $\mathbf{b}_{3}$ : The ratio of pollutant discharge between province $d_{j}$ and province $d_{k}$ should have a matching relationship with $\gamma_{\left(d_{j}, d_{k}\right)}$. It can be presented by Equation (9).

$$
\left[Q_{j} \cdot\left(W_{j}+Z_{j}\right)\right] /\left[Q_{k} \cdot\left(W_{k}+Z_{k}\right)\right] \in\left[\theta_{\min } \cdot \gamma_{\left(d_{j}, d_{k}\right)}, \theta_{\max } \cdot \gamma_{\left(d_{j}, d_{k}\right)}\right]
$$

where $j, k=1,2 \ldots n, j \neq k, \theta_{\min }$ and $\theta_{\max }$ are coefficients of the lower limit and upper limit which respectively reflect the matching relationship between the pollutant discharge of the province and comprehensive socio-economic indexes.

\subsubsection{Criteria c: Discriminant Criteria of Water Use Efficiency}

Criteria c: the discriminant criteria of the water use efficiency includes two aspects: the water use efficiency of the basin (criterion $c_{1}$ ) and the water use efficiency of the province (criterion $c_{2}$ ).

- Criterion $\mathbf{c}_{1}$ : the discriminant analysis for the water use efficiency of the basin can be expressed by Equation (10).

$$
\left[\sum_{j=1}^{n} W_{j}+\left(Z_{g}+\sum_{j=1}^{n} Z_{j}\right)\right] / G D P_{L} \leq E_{L H}
$$

where $G D P_{L}$ is the GDP of the basin and $E_{L H}$ is the control quota (the red line) for the water use amount per ten thousand yuan GDP of the basin.

- Criterion $c_{2}$ : the discriminant analysis for the water use efficiency of the province can be set by Equation (11).

$$
\left(W_{j}+Z_{j}\right) / G D P_{j} \leq E_{j H}
$$

where $G D P_{j}$ is the GDP of province $d_{j}$ and $E_{j H}$ is the control quota (the red line) for the water use amount per ten thousand yuan GDP of the province.

\subsubsection{Criteria d: Comprehensive Discriminant Analysis (Coupling and Coordination)}

Criteria d: according to the discriminant analysis results of criteria a, criteria $b$ and criteria $c$, the comprehensive discriminant analysis of the coupling and coordination criteria $\mathrm{d}$ can be established and are shown in Table 3. 
Table 3. The coupling and coordination Criteria (Criteria d).

\begin{tabular}{cl}
\hline Result & \multicolumn{1}{c}{ Discriminant Conditions } \\
\hline Uncoordinated & $\begin{array}{l}\text { Fail to pass any of the criteria: criterion } \mathrm{a}_{1}, \text { criterion } \mathrm{a}_{2}, \text { criterion } \mathrm{b}_{1}, \text { criterion } \mathrm{b}_{2}, \\
\text { criterion } \mathrm{c}_{1} \text { and criterion } \mathrm{c}_{2} .\end{array}$ \\
\hline Less Coordinated & $\begin{array}{l}\text { Pass criterion } \mathrm{a}_{1}, \text { criterion } \mathrm{a}_{2}, \text { criterion } \mathrm{b}_{1}, \text { criterion } \mathrm{b}_{2}, \text { criterion } \mathrm{c}_{1} \text { and criterion } \mathrm{c}_{2} . \\
\text { However, at the same time, fail to pass any of criterion } \mathrm{a}_{3}, \text { criterion } \mathrm{a}_{4} \text { and criterion } \mathrm{b}_{3} .\end{array}$ \\
\hline Coordinated & $\begin{array}{l}\text { Pass all criteria, namely criterion } \mathrm{a}_{1}, \text { criterion } \mathrm{a}_{2}, \text { criterion } \mathrm{a}_{3}, \text { criterion } \mathrm{a}_{4}, \text { criterion } \mathrm{b}_{1}, \\
\text { criterion } \mathrm{b}_{2}, \text { criterion } \mathrm{b}_{3}, \text { criterion } \mathrm{c}_{1} \text { and criterion } \mathrm{c}_{2} .\end{array}$ \\
\hline
\end{tabular}

\subsection{An Adjusted Decision-Making Model on the Assignment for the Initial Water Entitlements of the Basin}

From these above results about the comprehensive discriminant analysis (criteria d), if pre-allocation plans for the two subsystems are coordinated, then we get the optimal plans for the assignment of the initial water entitlements of the basin. However, if pre-allocation plans are uncoordinated or less coordinated, then plans need to be adjusted as follows:

Step 1: we need to decide the direction (increase or decrease) of adjustment for the pre-allocation plans for the two subsystems.

- (1) Considering criterion $\mathrm{a}_{1}$, criterion $\mathrm{b}_{1}$ and criterion $\mathrm{c}_{1}$, if any of them failed to pass, we should decrease the amount of the initial water entitlements of these two subsystems simultaneously.

- (2) If criterion $a_{1}$, criterion $b_{1}$ and criterion $c_{1}$ can be passed, however any one of criterion $a_{2}$, criterion $b_{2}$ and criterion $c_{2}$ failed to pass, then we should decrease the amount of water entitlements for province $d_{j}$. Here, we can define $d_{j} \in D$, and $D$ is the province set for decreasing water entitlements.

- (3) When all of these criterion $a_{1}$, criterion $b_{1}$, criterion $c_{1}$, criterion $a_{2}$, criterion $b_{2}$ and criterion $c_{2}$ can be passed, we should observe criterion $a_{3}$. If $\left(Z_{g}+\sum_{j=1}^{n} Z_{j}\right) / W_{L H} \leq \alpha_{\min }$, the amount of the government reserved water should be increased and the total amount of initial water entitlements at the province-level should be decreased. If $\left(Z_{g}+\sum_{j=1}^{n} Z_{j}\right) / W_{L H} \geq \alpha_{\max }$, the reverse is true. The quantity of the government reserved water should be decreased, and the total amount of initial water entitlements at the province-level should be increased. Furthermore, according to criterion $\mathrm{a}_{4}$, we can decide the specific province set of pre-allocation plans that needs to adjust. That is, if $\left(W_{j}+Z_{j}\right) /\left(W_{k}+Z_{k}\right) \geq \eta_{\max } \cdot \gamma_{\left(d_{j}, d_{k}\right)}$, then define $d_{j} \in D$, where $D$ is the province set for decreasing water entitlements. If $\left(W_{j}+Z_{j}\right) /\left(W_{k}+Z_{k}\right) \leq \eta_{\min } \cdot \gamma_{\left(d_{j}, d_{k}\right)}$, then define $d_{j} \in G$, where $G$ is the province set for increasing water entitlements.

Step 2: Taking coupling and coordination as the optimal objective and putting the total water use, the total pollutant discharge and the water use efficiency as constraint conditions, we propose an adjusted decision-making model for the assignment of the initial water entitlements of the basin. Given the situation that the total amount of initial water entitlements of provinces should be reduced and the amount of the government reserved water should be increased, the optimized decision-making model for adjustment can be described as follows:

If province $d_{j} \in D$, set $\Delta W_{j}$ as the adjustment amount of the initial water entitlements to province $d_{j}$, here $j=1,2 \ldots, n$. Then initial water entitlements for province $d_{j}$ can be adjusted as $\left(W_{j}-\Delta W_{j}\right)$. After the adjustment of the government reserved water, the public water use for the basin can be adjusted as $\left(Z_{g}+\Delta Z_{g}\right)$, and the public water use for different provinces can be adjusted as $\left(Z_{j}+\Delta Z_{j}\right)$, where $\Delta Z_{g} \geq 0, \Delta Z_{j} \geq 0$ and $j=1,2 \ldots, n$. Then, we can set Equations (12)-(14) as follows:

$$
P_{1}=\left\{\left[\left(Z_{g}+\Delta Z_{g}\right)+\sum_{j=1}^{n}\left(Z_{j}+\Delta Z_{j}\right)\right] / W_{L H}-\left(\alpha_{\min }+\alpha_{\max }\right) / 2\right\}^{2}
$$




$$
\begin{gathered}
P_{2}=\sum_{k=1}^{n} \sum_{j=1}^{n}\left\{\frac{\left[\left(W_{j}-\Delta W_{j}\right)+\left(Z_{j}+\Delta Z_{j}\right)\right]}{\left[\left(W_{k}-\Delta W_{k}\right)+\left(Z_{k}+\Delta Z_{k}\right)\right]}-\frac{\left(\eta_{\min }+\eta_{\max }\right)}{2} \gamma_{\left(d_{j}, d_{k}\right)}\right\}^{2} \\
P_{3}=\sum_{k=1}^{n} \sum_{j=1}^{n}\left\{\frac{Q_{j}\left[\left(W_{j}-\Delta W_{j}\right)+\left(Z_{j}+\Delta Z_{j}\right)\right]}{Q_{k}\left[\left(W_{k}-\Delta W_{k}\right)+\left(Z_{k}+\Delta Z_{k}\right)\right]}-\frac{\left(\theta_{\min }+\theta_{\max }\right)}{2} \gamma_{\left(d_{j}, d_{k}\right)}\right\}^{2}
\end{gathered}
$$

Afterwards, we can establish the objective function for the purpose of optimal coupled coordination. It can be presented by Equation (15).

$$
\operatorname{MinZ}=\omega_{1} \cdot P_{1}+\omega_{2} \cdot P_{2}+\omega_{3} \cdot P_{3}
$$

Furthermore, the relevant constraint conditions of our model can be described by the following equations:

$$
\begin{aligned}
& \Delta Z_{g}+\sum_{j=1}^{n} \Delta Z_{j} \leq \sum_{j=1}^{n} \Delta W_{j} \\
& \sum_{j=1}^{n}\left(W_{j}-\Delta W_{j}\right)+\left[\left(Z_{g}+\Delta Z_{g}\right)+\sum_{j=1}^{n}\left(Z_{j}+\Delta Z_{j}\right)\right] \leq W_{L H} \\
& \left(W_{j}-\Delta W_{j}\right)+\left(Z_{j}+\Delta Z_{j}\right) \leq W_{j H}, j=1,2 \ldots, n \\
& \alpha_{\min } \leq\left[\left(Z_{g}+\Delta Z_{g}\right)+\sum_{j=1}^{n}\left(Z_{j}+\Delta Z_{j}\right)\right] / W_{L H} \leq \alpha_{\max } \\
& \eta_{\min } \cdot \gamma_{\left(d_{j}, d_{k}\right)} \leq \frac{\left(W_{j}-\Delta W_{j}\right)+\left(Z_{j}+\Delta Z_{j}\right)}{\left(W_{k}-\Delta W_{k}\right)+\left(Z_{k}+\Delta Z_{k}\right)} \leq \eta_{\max } \cdot \gamma_{\left(d_{j}, d_{k}\right)}, \quad j, k=1,2 \ldots n, j \neq k \\
& \sum_{j=1}^{n} Q_{j}\left[\left(W_{j}-\Delta W_{j}\right)+\left(Z_{j}+\Delta Z_{j}\right)\right]+Q_{g} \cdot\left(Z_{g}+\Delta Z_{g}\right) \leq Q_{L H} \\
& Q_{j} \cdot\left[\left(W_{j}-\Delta W_{j}\right)+\left(Z_{j}+\Delta Z_{j}\right)\right] \leq Q_{j H}, j=1,2 \ldots n \\
& \theta_{\min } \cdot \gamma_{\left(d_{j}, d_{k}\right)} \leq \frac{Q_{j} \cdot\left[\left(W_{j}-\Delta W_{j}\right)+\left(Z_{j}+\Delta Z_{j}\right)\right]}{Q_{k} \cdot\left[\left(W_{k}-\Delta W_{k}\right)+\left(Z_{k}+\Delta Z_{k}\right)\right]} \leq \theta_{\max } \cdot \gamma_{\left(d_{j}, d_{k}\right)} \\
& \left\{\sum_{j=1}^{n}\left(W_{j}-\Delta W_{j}\right)+\left[\left(Z_{g}+\Delta Z_{g}\right)+\sum_{j=1}^{n}\left(Z_{j}+\Delta Z_{j}\right)\right]\right\} / G D P_{L} \leq E_{L H} \\
& \omega_{1}+\omega_{2}+\omega_{3}=1 \\
& \Delta W_{j} \geq 0, j=1,2 \ldots n \\
& \Delta Z_{j} \geq 0, j=1,2 \ldots n \\
& \Delta Z_{g} \geq 0, j=1,2 \ldots n
\end{aligned}
$$

Vice versa, a similar model is also available for the opposite situation, that is, the amount of the government reserved water should be decreased and the total amount of initial water entitlements at the province-level should be increased. This part is not elaborated here. Since Equations (12)-(28) are an NP model, we can use the adaptive chaotic optimization algorithm [61] to obtain the solutions.

\section{Discussion}

\subsection{Discriminant Analysis of the Pre-Allocation Plans}

4.1.1. Criteria a: Discriminant Analysis of the Total Water Use

(1) Discriminant Analysis for the Scale 
Criterion a a : according to the data in Table 2, we can calculate the results as follows: $\sum_{j=1}^{3} W_{j}=$ $W_{1}+W_{2}+W_{3}=335.4$ hundred million $\mathrm{m}^{3},\left(Z_{g}+\sum_{j=1}^{3} Z_{j}\right)=7.90$ hundred million $\mathrm{m}^{3}, W_{L H}=$ 363.3 hundred million $\mathrm{m}^{3}$. These above results satisfy the Equation (2), so criterion $\mathrm{a}_{1}$ can be passed.

Criterion $\mathbf{a}_{2}$ : According to the materials "The provincial government planning for Lake Tai basin", the control quotas (the first red line) of the total water use by the planned year 2030 can be expressed as follows: $W_{1 H}=600$ hundred million $\mathrm{m}^{3}$ (Jiangsu province), $W_{2 H}=244.4$ hundred million $\mathrm{m}^{3}$ (Zhejiang Province), $W_{3 H}=285.15$ hundred million $\mathrm{m}^{3}$ (Shanghai). Then, according to the data in Table 2, the discriminant results of the total water use can be calculated by Equation (3) just as follows: $W_{1}+Z_{1}=$ $179.49<W_{1 H}=600$ hundred million $\mathrm{m}^{3}$ (Jiangsu Province), $W_{2}+Z_{2}=94.14<W_{2 H}=244.4$ hundred million $\mathrm{m}^{3}$ (Zhejiang Province) and $W_{3}+Z_{3}=86.51<W_{3 H}=285.15$ hundred million $\mathrm{m}^{3}$ (Shanghai). It can be seen that the results meet the requirements of Equation (3) and pass criterion $\mathrm{a}_{2}$.

(2) Discriminant analysis for structure

Criterion $\mathbf{a}_{3}$ : Set the rational interval for the proportion of the water amount between the government reserved water and the available water of the basin $\left[\alpha_{\min }, \alpha_{\max }\right] \in[0.025,0.075]$. According to the data in Table 2 and Equation (4), we can get the result as follows: $\left(Z_{g}+\sum_{j=1}^{3} Z_{j}\right) / W_{L H}=$ $0.0217<\alpha_{\min }=0.025$. It failed to pass criterion $\mathrm{a}_{3}$ and indicates that the amount of the government reserved water is not enough.

Criterion $\mathbf{a}_{4}$ : Using the materials about "Water Resources Bulletin of Lake Tai Basin \& Southeast Rivers (2003-2016)" and "Water Resources plan for Lake Tai Basin (2012-2030)", the related index data for criterion $\mathrm{a}_{4}$ in Lake Tai Basin have been shown in Table 1. The weight coefficient in Equation (5) is obtained by the combination of expert opinion and the actual provincial situation in Lake Tai Basin. It can be expressed as $\omega_{q}=(0.2,0.2,0.25,0.35)$. The coefficient of the lower limit which reflects the matching relationship between the initial water entitlements at the province-level and comprehensive socio-economic indexes can be set as $\eta_{\min }=0.7$, and the upper limit coefficient can be set as $\eta_{\max }=$ 1.6. Then, the discriminant results of criterion $\mathrm{a}_{4}$ can be obtained by Equations (5) and (6), which are presented in Table 4 . It can be found that province pairs of $\left(d_{1}, d_{3}\right)$ and $\left(d_{2}, d_{3}\right)$ failed to pass criterion $\mathrm{a}_{4}$ in Table 4.

Table 4. Discriminant results of criterion $\mathrm{a}_{4}$.

\begin{tabular}{cccccc}
\hline Province Pair & $\left(\boldsymbol{W}_{j}+Z_{j}\right) /\left(\boldsymbol{W}_{\boldsymbol{k}}+Z_{\boldsymbol{k}}\right)$ & $\gamma_{\left(\boldsymbol{d}_{j}, \boldsymbol{d}_{k}\right)}$ & $\eta_{\min } \cdot \gamma_{\left(\boldsymbol{d}_{j}, \boldsymbol{d}_{k}\right)}$ & $\eta_{\max } \cdot \gamma_{\left(\boldsymbol{d}_{j}, \boldsymbol{d}_{k}\right)}$ & Discriminant Results \\
\hline$\left(d_{1}, d_{2}\right)$ & 1.91 & 2.41 & 1.69 & 3.86 & $1.91 \in[1.69,3.86]$, Pass \\
\hline$\left(d_{1}, d_{3}\right)$ & 2.07 & 1.27 & 0.89 & 2.03 & $2.07 \notin[0.89,2.03]$, Fail to pass \\
\hline$\left(d_{2}, d_{3}\right)$ & 1.09 & 0.61 & 0.43 & 0.98 & $1.09 \notin[0.43,0.98]$, Fail to pass \\
\hline
\end{tabular}

4.1.2. Criteria b: Discriminant Analysis for the Total Pollutant Discharge

(1) Discriminant analysis for the scale

Criterion $\mathbf{b}_{\mathbf{1}}$ : Using the materials of "Water Resources Bulletin of Lake Tai Basin \& Southeast Rivers (2003-2016)", the annual average coefficient of unit pollutant discharge for different provinces can be presented respectively as $Q_{1}=0.15$ (Jiangsu Province), $Q_{2}=0.13$ (Zhejiang Province), $Q_{3}=0.16$ (Shanghai); the annual average coefficient of the unit pollutant discharge for the public water use of the basin is known as $Q_{g}=0.15$. According to the materials of "Water Resources plan of Lake Tai Basin (2012-2030)", the control quota (the second red line) for the total pollutant discharge of the basin can be illustrated as $Q_{L H}=5.446$ billion $\mathrm{m}^{3}$. According to the data in Table 2 and Equation (7), we can obtain the result of the discriminant analysis for the total pollutant discharge of the basin which is written as follows: $\sum_{j=1}^{3} Q_{j} \cdot\left(W_{j}+Z_{j}\right)=53.03$ hundred million $\mathrm{m}^{3}$ and $Q_{g} \cdot Z_{g}=0.47$ hundred million $\mathrm{m}^{3}$, then $\sum_{j=1}^{3} Q_{j} \cdot\left(W_{j}+Z_{j}\right)+Q_{g} \cdot Z_{g}=53.5<Q_{L H}=54.46$ hundred million $\mathrm{m}^{3}$. The result meets the requirement of Equation (7) and pass criterion $b_{1}$. 
Criterion $\mathbf{b}_{2}$ : According to the materials "Provincial Environmental Bulletin for Lake Tai Basin" and the relevant planning reports, in the planning year 2030, the control quotas (the red line) for the total pollutant discharge of different provinces can respectively be presented as $Q_{1 H}=50.32$ hundred million $\mathrm{m}^{3}$ (Jiangsu province), $Q_{2 H}=35.62$ hundred million $\mathrm{m}^{3}$ (Zhejiang Province) and $Q_{3 H}=21.57$ hundred million $\mathrm{m}^{3}$ (Shanghai). According to Equation (8), we can obtain the discriminant results of the total pollutant discharge in different provinces which can be expressed as follows: $Q_{1} \cdot\left(W_{1}+Z_{1}\right)=26.9<Q_{1 H}=50.32$ hundred million $\mathrm{m}^{3}$ (Jiangsu Province), $Q_{2} \cdot\left(W_{2}+Z_{2}\right)=$ $12.24<Q_{2 H}=35.62$ hundred million $\mathrm{m}^{3}$ (Zhejiang Province) and $Q_{3} \cdot\left(W_{3}+Z_{3}\right)=13.84<Q_{3 H}=$ 21.57 hundred million $\mathrm{m}^{3}$ (Shanghai). So, criterion $\mathrm{b}_{2}$ can be passed according to the above three results.

(2) Discriminant analysis for structure

Criterion $b_{3}$ : Taking into account expert opinions and the actual situation of different provinces in Lake Tai Basin, set $\theta_{\min }=0.75$ and $\theta_{\max }=1.6$ as the lower limit and the upper limit coefficient which, respectively, reflect the matching relationship between the total pollutant discharge of the province and comprehensive socio-economic indexes. The discriminant results of criterion $b_{3}$ can be obtained by Equation (9), which is presented in Table 5. Then, criterion $b_{3}$ can be passed.

Table 5. Discriminant results of criterion $b_{3}$.

\begin{tabular}{cccccc}
\hline Province Pair & {$\left[\boldsymbol{Q}_{j} \cdot\left(\boldsymbol{W}_{j}+Z_{j}\right)\right] /\left[\boldsymbol{Q}_{\boldsymbol{k}} \cdot\left(\boldsymbol{W}_{\boldsymbol{k}}+\boldsymbol{Z}_{\boldsymbol{k}}\right)\right]$} & $\boldsymbol{\gamma}_{\left(\boldsymbol{d}_{j}, \boldsymbol{d}_{k}\right)}$ & $\boldsymbol{\theta}_{\min } \cdot \gamma_{\left(\boldsymbol{d}_{j}, \boldsymbol{d}_{k}\right)}$ & $\boldsymbol{\theta}_{\max } \cdot \gamma_{\left(d_{j}, \boldsymbol{d}_{k}\right)}$ & Discriminant Results \\
\hline$\left(d_{1}, d_{2}\right)$ & 2.20 & 2.41 & 1.81 & 3.85 & $2.2 \in[1.81,3.85]$, Pass \\
\hline$\left(d_{1}, d_{3}\right)$ & 1.95 & 1.27 & 0.95 & 2.03 & $1.95 \in[0.95,2.03]$, Pass \\
\hline$\left(d_{2}, d_{3}\right)$ & 0.88 & 0.61 & 0.46 & 0.98 & $0.88 \in[0.46,0.98]$, Pass \\
\hline
\end{tabular}

\subsubsection{Criteria c: Discriminant Analysis for Water Use Efficiency}

(1) Discriminant analysis for water use efficiency of the basin

Criterion $c_{1}$ : According to the materials "Provincial Environmental Bulletin for Lake Tai Basin" and the relevant planning reports, the control quota (the third red line) for the water use amount per ten thousand yuan GDP of the basin can be set as $E_{L H}=31.87 \mathrm{~m}^{3} /$ ten thousand Yuan. Using Equation (10), it can be calculated $\left[\sum_{j=1}^{3} W_{j}+\left(Z_{g}+\sum_{j=1}^{3} Z_{j}\right)\right] / G D P_{L}=28.69 \mathrm{~m}^{3} /$ ten thousand Yuan. This result can meet the discriminant analysis for the water efficiency of the basin and criterion $c_{1}$ can be passed.

(2) Discriminant analysis for the water use efficiency of different provinces

Criterion $c_{2}$ : According to provincial planning and expert opinions about water resources management for Lake Tai Basin, the control quota (the red line) for the water use amount per ten thousand yuan GDP of different provinces can be presented respectively as: $E_{1 H}=40 \mathrm{~m}^{3} /$ ten thousand Yuan (Jiangsu Province), $E_{2 H}=35 \mathrm{~m}^{3} /$ ten thousand Yuan (Zhejiang Province) and $E_{3 H}=38 \mathrm{~m}^{3} /$ ten thousand Yuan (Shanghai). Using the data in Table 1, the real water consumption per unit GDP in different provinces can be calculated respectively as: $39.47 \mathrm{~m}^{3} /$ ten thousand Yuan (Jiangsu Province), $22.67 \mathrm{~m}^{3}$ /ten thousand Yuan (Zhejiang Province) and $37.85 \mathrm{~m}^{3} /$ ten thousand Yuan (Shanghai). By Equation (11), the results can pass the criterion $c_{2}$.

\subsubsection{Criteria d: Comprehensive Discriminant Analysis}

In summary, from the above discriminant analysis, since the pre-allocation plans failed to pass criterion $\mathrm{a}_{3}$ and criterion $\mathrm{a}_{4}$, according to criteria $\mathrm{d}$ in Table 3 , we can draw the conclusion that the pre-allocation plans are uncoordinated and need to be adjusted. 


\subsection{Plan Adjustment}

(1) Step 1: First, because we failed to pass criterion $a_{3}$, and $\left(Z_{g}+\sum_{j=1}^{3} Z_{j}\right) / W_{L H}<\alpha_{\min }$, we should increase the amount of the government reserved water for Lake Tai Basin. Second, because province pair $\left(d_{1}, d_{3}\right)$ and $\left(d_{2}, d_{3}\right)$ failed to pass criterion $\mathrm{a}_{4}$, and $\left[\left(W_{1}+Z_{1}\right) /\left(W_{3}+Z_{3}\right)\right]=2.07 \geq$ $\eta_{\max } \cdot \gamma_{\left(d_{1}, d_{3}\right)}=2.04,\left[\left(W_{2}+Z_{2}\right) /\left(W_{3}+Z_{3}\right)\right]=1.09 \geq \eta_{\max } \cdot \gamma_{\left(d_{2}, d_{3}\right)}=0.98$, according to the adjustment strategies, we can determine that $D=\left\{d_{1}, d_{2}\right\}$ is the province set for decreasing water entitlements of the pre-allocation plans. Furthermore, the provincial water entitlements of the pre-allocation plans should be decreased in Jiangsu Province and Zhejiang Province.

(2) Step 2: After the adjustment of the government reserved water, the public water use for Lake Tai Basin can be adjusted as $\left(3.16+\Delta Z_{g}\right)$ hundred million $\mathrm{m}^{3}$ and the public water use for different provinces in Lake Tai Basin can be adjusted as follows: $\left(2.50+\Delta Z_{1}\right)$ hundred million $\mathrm{m}^{3}$ in Jiangsu Province, $\left(1.03+\Delta Z_{2}\right)$ hundred million $\mathrm{m}^{3}$ in Zhejiang Province and $\left(1.21+\Delta Z_{3}\right)$ hundred million $\mathrm{m}^{3}$ in Shanghai, where $\Delta Z_{g} \geq 0 ; \Delta Z_{j} \geq 0 ; j=1,2,3$. The adjusted provincial water entitlements of the pre-allocation plans can be described as $\left(176.99-\Delta W_{1}\right)$ hundred million $\mathrm{m}^{3}$ in Jiangsu Province, and $\left(93.11-\Delta W_{2}\right)$ hundred million $\mathrm{m}^{3}$ in Zhejiang Province.

According to our model by Equations (12)-(28), the whole routine can be programmed in MATLAB 2015b. The adjusted assignment plans are shown in Table 6. Based on the discriminant criteria in this paper, the adjusted plans unanimously pass Criteria a, Criteria b, Criteria $\mathrm{c}$ and Criteria d. Therefore, the new plans are valid.

Table 6. Adjusted assignment plans of the two subsystems in Lake Tai Basin (unit: a hundred million $\mathrm{m}^{3}$ ).

\begin{tabular}{|c|c|c|c|c|c|}
\hline & \multicolumn{2}{|c|}{ Adjusted Assignment Plans in Different Provinces } & $\begin{array}{l}\text { Jiansu } \\
\text { Province }\end{array}$ & $\begin{array}{l}\text { Zhejiang } \\
\text { Province }\end{array}$ & Shanghai City \\
\hline Subsystem 1 & $\begin{array}{l}\text { Amount of the initial water } \\
\text { entitlements at } \\
\text { province-level }\end{array}$ & & $W_{1}=169.97$ & $W_{2}=83.12$ & $W_{3}=85.3$ \\
\hline \multirow[t]{2}{*}{ Subsystem 2} & \multirow{2}{*}{$\begin{array}{l}\text { Amount of the government } \\
\text { reserved water at river } \\
\text { basin-level }\end{array}$} & $\begin{array}{l}\text { Public water use for } \\
\text { different provinces }\end{array}$ & $Z_{1}=7.89$ & $Z_{2}=3.26$ & $Z_{3}=3.80$ \\
\hline & & $\begin{array}{l}\text { Public water use for } \\
\text { Lake Tai Basin }\end{array}$ & & $Z_{g}=9.96$ & \\
\hline
\end{tabular}

On 4 May, 2018, China's Ministry of Water Resources released the pilot assignment plans about the initial water entitlements for Lake Tai Basin. Compared to this pilot's plans, we got the following findings: (1) Under the water frequency of $75 \%$, in the planning year 2030, our assignment plans of the subsystem of the initial water entitlements at the province-level are generally in accordance with the pilot ones, that is, Jiangsu Province is assigned the most initial water entitlements at the province-level, followed by Shanghai City and Zhejiang Province. (2) The pilot assignment plans of Lake Tai Basin fail to consider the government reserved water of the basin. Apart from the pilot plans, our assignment methodology not only involved the government reserved water at the river basin-level, however it also established a new framework for the co-ordination and coupling assignment of the initial water entitlements for the basin. Our coupled assignment method embedded the requirements of the strictest water resources management which key content is "The three red lines" control, also emphasizes initial water entitlements at the province-level and government reserved water at the river basin-level should be taken into account simultaneously during assignment for the initial water entitlements at the river basin-level.

\section{Conclusions}

Establishing the water market is advocated as a very useful economic policy initiative to address increasing water resource shortages around the world. Due to the ongoing water reform about implementing China's strictest water management, the challenge of assigning the initial water entitlements should be the crucial foundation and prerequisite of the water market in China. In 
this paper, our focus was on seeking fair, efficient and reasonable assignment plans of initial water entitlements at the river basin-level under the strictest water management system constraints. The conclusions of this research are as follows:

First, from the perspective of system science, the assignment system of the initial water entitlements at the river basin-level can be divided into two subsystems, namely the assignment subsystem of the initial water entitlements at the province-level and the government reserved water of the basin.

Second, due to severe negative social and environmental consequences, at the river basin-level, in order to prevent unforeseeable future events and emergencies, government reserved water should be taken into account simultaneously during the assignment for the initial water entitlements at the river basin-level. It also important to highlight that the assignment of government reserved water should also be coordinated and coupled with the assignment plans for the initial water entitlements at the province-level.

Third, following the strictest water management requirements, the design for the discriminant criteria should comply with the "three red lines" control. The discriminant criteria of the total water use, the total pollutant discharge and water use efficiency are separately expressed by Criteria a, Criteria $b$ and Criteria c. Based on these criteria, the comprehensive Criteria d should be designed for the discriminant analysis of the coupling and coordination situation between the two subsystems.

Fourth, the case study of Lake Tai Basin shows with water frequency $75 \%$, in the planning year 2030, that Jiangsu Province is assigned the most initial water entitlements at the province-level, followed by Shanghai and Zhejiang Province. The results are generally in accordance with the pilot plan that was released by China's Ministry of Water Resources. Different from the pilot plans, the findings also show the assignment plans for the government reserved water at the river basin-level, which is coordinating and coupled with the assignment plans for the initial water entitlements at the province-level. The novel methodological framework in this paper can also be applied as a reference to similar river basin.

However, this paper still has its limitations. The climate change effects, the recovering of the water bodies, the groundwater, the water reuse and the reservoirs will gradually be taken into account in our future research.

Author Contributions: M.G. designed the structure of the paper and drafted the manuscript; F.W. carried out the empirical analysis; X.C. disposed the data and assisted with the empirical study; Y.G. disposed the data.

Funding: This work was supported by the National Natural Science Foundation of China (Grant No. 71774048; Grant No. 71301063), the support of " The Key Project of Philosophy and Social Science Research in Colleges and Universities in Jiangsu Province " (Research on the characteristic water entitlements trading mechanism in Lake Tai Basin based on water ecological security community, Grant No. 2018SJZDI048), the support of "the Fundamental Research Funds for the Central Universities for Hohai University" (Grant No. 26120172017B05514; Grant No. 2018B41914).

Acknowledgments: We would gratefully like to thank the anonymous reviewers for their valuable and helpful comments to improve our drafts. All remaining errors are ours.

Conflicts of Interest: No conflicts.

\section{References}

1. Simon, L.L.; Mark, A.M. Defining the Anthropocene. Nature 2015, 519, 171-180.

2. Wei, Y.P.; Zhang, Z.Q. Theory and Practice of Socio-Hydrology; Science Press: Beijing, China, 2018.

3. Peng, J.; Tian, L.; Liu, Y.X.; Zhao, M.Y.; Hu, Y.N.; Wu, J.S. Ecosystem services response to urbanization in metropolitan areas: Thresholds identification. Sci. Total Environ. 2017, 608, 706-714. [CrossRef] [PubMed]

4. Srinivasan, V.; Sanderson, M.; Garcia, M.; Konar, M.; Blöschl, G.; Sivapalan, M. Prediction in a socio-hydrological world. Hydrol. Sci. J. 2017, 62, 338-345. [CrossRef]

5. Blair, P.; Buytaert, W. Socio-hydrological modeling: A review asking "why, what and how"? Hydrol. Earth Syst. Sci. 2016, 20, 443-447. [CrossRef] 
6. $\quad$ Rodell, M.; Famiglietti, J.S.; Wiese, D.N.; Reager, J.T.; Beaudoing, H.K.; Landerer, F.W.; Lo, M.-H. Emerging trends in global freshwater availability. Nature 2018, 557, 651-659. [CrossRef] [PubMed]

7. World Economic Forum. The Global Risks 2018, 13th ed.; World Economic Forum: Geneva, Switzerland, 2018.

8. Tiziano, D.; Scott, K. Are we in deep water? Water scarcity and its limits to economic growth. Ecol. Econ. 2017, 142, 130-147.

9. Ge, M.; Wu, F.P.; Chen, X.P. A coupled allocation for regional initial water rights in Dalinghe Basin, China. Sustainability 2017, 9, 428. [CrossRef]

10. Chinese State Council. Advice on Applying the Strictest Water Resources Management. 2012. Available online: http:/ / www.gov.cn/zhuanti/2015-06/13/content_2878992.htm (accessed on 15 February 2012).

11. Global Water Partnership. China's Water Resources Management Challenge: The 'Three Red Lines'; Elanders: Mölnlycke, Sweden, 2015.

12. Endo, T.; Kakinuma, K.; Yoshikawa, S.; Kanae, S. Are water markets globally applicable? Environ. Res. Lett. 2018, 13, 034032. [CrossRef]

13. Alarcón, J.; Juana, L. The Water Markets as Effective Tools of Managing Water Shortages in an Irrigation District. Water Resour. Manag. 2016, 30, 2611-2625. [CrossRef]

14. Grafton, R.Q.; Horne, J.; Wheeler, S.A. On the Marketization of Water: Evidence from the Murray-Darling Basin, Australia. Water Resour. Manag. 2016, 30, 913-926. [CrossRef]

15. Bayer, R.; Loch, A. Experimental evidence on the relative efficiency of forward contracting and tradable entitlements in water markets. Water Resour. Econ. 2017, 20, 1-15. [CrossRef]

16. Wheeler, S.A.; Loch, A.C.; Lin, M.; Grafton, R.Q. Developing a Water Market Readiness Assessment Framework. J. Hydrol. 2017, 552, 807-820. [CrossRef]

17. Garbe, J.; Beevers, L. Modeling the impacts of a water trading scheme on freshwater habitats. Ecol. Eng. 2017, 105, 284-295. [CrossRef]

18. Eiji, S. Nontransferable water rights and technical inefficiency in the Japanese water supply industry. Water Resour. Econ. 2015, 11, 13-21.

19. Bekchanov, M.; Bhaduri, A.; Ringler, C. Potential gains from water rights trading in the Aral Sea Basin. Agric. Water Manag. 2015, 152, 41-56. [CrossRef]

20. Wheeler, S.A.; Zuo, A.; Bjornlund, H. Investigating the delayed on-farm consequences of selling water entitlements in the Murray-Darling Basin. Agric. Water Manag. 2014, 145, 72-82. [CrossRef]

21. Qureshi, M.E.; Shi, T.; Qureshi, S.; Proctor, W. Removing barriers to facilitate efficient water markets in the Murray-Darling Basin of Australia. Agric. Water Manag. 2009, 96, 1641-1651. [CrossRef]

22. Jiang, Q.; Grafton, R.Q. Economic effects of climate change in the Murray-Darling Basin. Aust. Agric. Syst. 2012, 110, 10-16. [CrossRef]

23. Coase, R.H. The Problem of Social Cost. J. Law Econ. 1960, 3, 1-44. [CrossRef]

24. Richter, B. Water Markets: A New Tool for Securing Urban Water Supplies? J. Am. Water Works Assoc. 2014, 3, 26-28. [CrossRef]

25. Elizabeth, K.D.; Leila, M.H. Framing community entitlements to water in Accra, Ghana: A complex reality. Geoforum 2017, 82, 26-39.

26. Wang, H.; Dang, L.; Xie, X.; Qi, Y. Theory and Practice on Allocation of Initial Water Entitlements in a Watershed; China Water Power Press: Beijing, China, 2008. (In Chinese)

27. Lia, D.; Richard, A.; Erick, S.; Tang, S.; Zhang, Y.; Niu, Z.C.; Liu, H.L.; Yua, H.X. Structure and spatial patterns of macrobenthic community in Tai Lake, a large shallow lake, China. Ecol. Indic. 2016, 61, 179-187. [CrossRef]

28. Ge, M.; Wu, F.P.; You, M. Initial Provincial Water Rights Dynamic Projection Pursuit Allocation Based on the Most Stringent Water Resources Management: A Case Study of Taihu Basin, China. Water 2017, 9, 35. [CrossRef]

29. Liu, Y.M.; Chen, W.; Li, D.H.; Huang, Z.B.; Shen, Y.W.; Liu, Y.D. Cyanobacteria-cyanotoxin/-contaminations and eutrophication status before Wuxi drinking water crisis in Lake Taihu, China. J. Environ. Sci. 2011, 23, 575-581. [CrossRef]

30. Li, J.Y.; Su, L.; Wei, F.H.; Yang, J.H.; Jin, L.; Zhang, X.W. Bioavailability-based assessment of aryl hydrocarbon receptor-mediated activity in Lake Tai Basin from Eastern China. Sci. Total Environ. 2016, 544, 987-994. [CrossRef] [PubMed] 
31. Xevi, E.; Khan, S. A Multi-objective Optimization Approach to Water Management. J. Environ. Manag. 2005, 77, 269-277. [CrossRef] [PubMed]

32. Read, L.; Madani, K.; Inanloo, B. Optimality versus stability in water resource allocation. J. Environ. Manag. 2014, 133, 343-354. [CrossRef] [PubMed]

33. Yang, W.; Sun, D.Z. A Genetic Algorithm-based Fuzzy Multi-objective Programming Approach for Environmental Water Allocation. Water Sci. Technol. Water Supply 2006, 6, 43-50. [CrossRef]

34. Wu, F.P.; Ge, M. Initial allocation model for water right of the first hierarchy. J. Hohai Univ. 2005, 2, $216-219$.

35. Ge, M.; Wu, F.P. Initial allocation model for water right of the second hierarchy. J. Hohai Univ. 2005, 33, 592-594.

36. Wu, F.P.; Ge, M. Method for interactive water right initial allocation based on harmoniousness judgment. J. Hohai Univ. 2006, 1, 104-107.

37. Wu, D.; Wu, F.P. Evaluation of the cooperative development validity among regions based on water entitlements initial allocation. Soft Sci. 2011, 25, 80-83.

38. Wu, D.; Wu, F.P. Optimization of industry oriented initial water entitlements allocation system. Adv. Sci. Technol. Water Resour. 2012, 32, 39-44.

39. Condon, L.E.; Maxwell, R.M. Implementation of a linear optimization water allocation algorithm into a fully integrated physical hydrology model. Adv. Water Resour. 2013, 60, 135-147. [CrossRef]

40. Wu, F.P.; Chen, Y.P. Research on the Harmonious Allocation Method of Initial Water Entitlements in a Basin; China Water Power Press: Beijing, China, 2010.

41. Wu, D.; Wu, F.P. The bi-level optimization model of the compound system for basin initial water right allocation. Syst. Eng. Theory Prac. 2012, 32, 196-202.

42. Wang, Z.Z.; Zhang, L.L.; Wang, Y.T.; Jing, J.L.; Cheng, L. Preliminary theoretical framework of water resources operation based on initial two-dimensional water rights in a basin. Adv. Water Sci. 2012, 23, 590-598.

43. Zhang, L.N.; Wu, F.P.; Jia, P. A preliminary theoretical framework of basin initial water entitlements allocation from a coupling perspective and when constrained by the strictest water resources management system. Resour. Sci. 2014, 36, 2240-2247.

44. Ge, M.; Wu, F.-P.; You, M. Provincial Initial Water Rights Incentive Allocation Model with Total Pollutant Discharge Control. Water 2016, 8, 525. [CrossRef]

45. Dou, M.; Wang, Y.Y. The construction of a water rights system in China that is suited to the strictest water resources management system. Water Sci. Technol. Water Supply 2016, 17, 238-245. [CrossRef]

46. Jenifer, L.T.; Allan, L.C. Can existing practices expected to lead to improved on-farm water use efficiency enable irrigators to effectively respond to reduced water entitlements in the Murray-Darling Basin? J. Hydrol. 2015, 528, 613-620.

47. Wang, H.; Wang, J.H.; Qin, D.Y. Research advances and direction on the theory and practice of reasonable water resources allocation. Adv. Water Sci. 2004, 15, 123-128.

48. Zhou, Y.; Wu, F.-P.; Chen, Y.P. Research status and motive analysis of governmental reserved water. Adv. Sci. Technol. Water Resour. 2012, 32, 83-88.

49. Zhou, Y.; Wu, F.-P.; Chen, Y.P. Emergency reserved water demand estimation for public events of accidental water source pollution. J. Nat. Resour. 2013, 28, 1426-1437.

50. Cheng, T.J.; Wu, F.-P. Application of reasoning method of improved case to forecast of reserved water for governmental emergency. J. Water Resour. Water Eng. 2016, 27, 1-5.

51. Xie, X.M.; Wang, Z.Z.; Wang, J.H.; Chi, P.C. Analysis on determination method of government-reserved water quantities for initial water right allocation in Song-Liao rivers basin. J. China Inst. Water Resour. Hydropower Res. 2006, 4, 128-132.

52. Shen, D.J.; Wang, J.H.; Xie, X.M. Research on use principle and management model of governmental reserved water. China Water Resour. 2006, 34-37. [CrossRef]

53. Sun, A.J.; Dong, Z.C.; Zhang, X.Y. Coupling Degree between Urban Economy and Technical Efficiency of Water Use in China. Resour. Sci. 2008, 30, 446-453.

54. Liu, L.P.; Tang, D.S. Evaluation and coupling coordination analysis on water resources scarcity and social adaptation capacity. J. Arid Land Resour. Environ. 2014, 28, 13-19.

55. Wang, Q.; Tang, F.H. Evaluation of the coupling coordination development of ecology-economy-society system. Econ. Geogr. 2015, 35, 161-202. 
56. Yin, F.Y.; Gong, B.; Wang, Y. The coupling mechanism of water environment and urbanization. Seeker 2016, 1 , 84-88.

57. Yan, Z.Q.; Wang, H.; Sang, X.F.; Chu, J.Y.; Liu, Y. Dynamical management for total amount control of water resources utilization based on fuzzy cluster analysis and sequential decision. J. China Inst. Water Resour. Hydropower Res. 2017, 14, 161-169.

58. Jin, J.L.; Fei, Z.Y.; Li, J.Q.; Zhou, Y.L. Method for evaluating the regional drought resistance ability based on the analysis of water balance between supply and demand with different water frequencies. J. Hydraul. Eng. 2013, 44, 687-693.

59. Hou, B.D.; Gao, E.K.; Wu, Y.X.; Zhan, X.Z.; Wang, G.X.; Wu, K. Water resources demand hierarchy theory and preliminary practice. Adv. Water Sci. 2014, 25, 897-906.

60. Wei, G.H.; Zhang, L.C.; Jiang, Z.Y. Quantitative Analysis on Runoff Loss in Upper and Middle Reaches of Tarim River. Pearl River 2018, 39, 34-37.

61. Wang, S.; Cheng, C.T.; Wu, X.Y.; Li, B.J. Application of self-adaptive chaos whole annealing genetic algorithm to optimal operation of hydropower station groups. J. Hydroelectr. Eng. 2014, 33, 63-71.

(C) 2018 by the authors. Licensee MDPI, Basel, Switzerland. This article is an open access article distributed under the terms and conditions of the Creative Commons Attribution (CC BY) license (http:/ / creativecommons.org/licenses/by/4.0/). 